\title{
The Role of the Information Society in Promoting a Better and a More Democratic Governance
}

\author{
Imane Hijal-Moghrabi \\ Assistant Professor \\ Public Administration and Leadership Program \\ The University of Texas of the Permian Basin \\ 4901 E. University, Odessa, Texas 79762, USA \\ Meghna Sabharwal \\ Associate Professor and PhD Advisor \\ Public and Nonprofit Management \\ School of Economic, Political and Policy Sciences \\ University of Texas at Dallas \\ 800 W. Campbell Road, GR 31 \\ Richardson, TX 75080, USA
}

Received: Oct. 20, 2017 Accepted: Nov. 10, 2017 Online published: Nov. 13, 2017

doi:10.5296/jpag.v7i4.12018ＵRL: https://doi.org/10.5296/ jpag.v7i4.12018

\begin{abstract}
One of the major shifts that our society has witnessed in the past few decades is the paradigm shift from traditional bureaucracies to network arrangements in policy making and service delivery. This paper explores the New Governance as a paradigm shift in Public Administration with an emphasis on the democratic aspect of it. Approaching the New Governance from an Open Systems Theory perspective, this paper argues that the advent and the widespread use of ICTs and the "infosphere" - and the "information society" that has emerged from it - would help in promoting a better and a more democratic governance by providing new channels to put democracy into practice. This paper also acknowledges the dark side of the "infosphere" and the ethical challenges that have come along with it.
\end{abstract}

Keywords: the new governance, governance networks, open system, the infosphere, 
information society, democratic governance, information and communication technologies (ICTs)

\section{Introduction}

Writing in 1966, Warren Bennis observed that every age develops an organizational lifestyle most appropriate to the genius of that age (Bennis, 1966). One of the major shifts that our society has witnessed in the past few decades is the paradigm shift from traditional bureaucracies to network arrangements in policy making and service delivery. Hierarchical structures that served society so well in the past as the primary provider of public services, no longer fit a society of growing needs and demands. Even the markets have fallen short of filling this gap. The failure of government and the market models in meeting the pressing demands of society has allowed for an emergence of a new form of governance - variously referred to as "governing without government" (Rhodes, 1994, 1996, 1997; Peters \& Pierre, 1998), "self-organizing and interdependent networks" (O'Toole, 1997a, 1997b), and "collaborative public management" (Agranoff, 2006; Agranoff \& McGuire, 2001, 2003; McGuire, 2006; McGuire, Agranoff, \& Silvia, 2010).

While some public administration scholars find in this shift a clear departure from the democratic ethos and a threat to the traditional image of liberal democracy (Rhodes, 1996, 1997), others see in it an opportunity to reconceptualize and reframe democracy to make it more in line with our contemporary society (Boyte, 2005; O’Toole, 1997b; Sørensen, 2000; Sørensen \& Torfing, 2003).

This paper looks at the new governance from an Open Systems Theory (Katz \& Khan, 1966) perspective. This approach postulates that organizations are in constant touch with their external environment. The environment provides organizations with resources (people, funds, information, etc.) as well as with constraints (laws, regulations, and other challenges). This environment - whether social, political, or economic - greatly affects and shapes how organizations operate. Government and its collaborative partners are no exception. Among these environmental forces is the advent of Information and Communication Technologies (ICTs) in the past few decades that has dramatically changed our life, our society, and our institutions.

Approaching the New Governance from an Open Systems Theory perspective, this paper argues that the advent and the widespread use of ICTs and the "infosphere" - and the "information society" that has emerged from it - would help in promoting a better and a more democratic governance by providing new channels to put democracy into practice. This paper also acknowledges the dark side of the "infosphere" and the ethical challenges that have come along with it.

Hence, this paper explores the New Governance as a paradigm shift in Public Administration with an emphasis on the democratic aspect of it. Next, the paper discusses how the information society would help in promoting better governance that is more compatible with the ideals of liberal democracy, and addresses the ethical challenges that the infosphere presents. Finally, the paper provides guidelines for public and private mangers in 
collaborative networks and proposes topics for future research.

\section{The New Governance: A Paradigm Shift}

During the last century, the scope of government expanded to cover all aspects of our life. Government emerged as the primary provider of goods and services. However, the traditional model with its hierarchical structure and long chain of commands was found outmoded and incapable of keeping up with the ever-changing and increasing demands of society. Toward the end of the $20^{\text {th }}$ Century, government was no longer solely responsible for the provision of public services (Kettle, 1993; Salamon, 2002). Most of government programs and services have been ever since provided by "a host of nongovernmental third party surrogates or proxies that provide programs under the agencies loans, loan guarantees, grants, contracts, and other tools of public administration" (Salamon, 2002, pp. 1-2).

Thus, governance denotes a shift from traditional structures to network structures - in other words, from "hierarchy to heterarchy" (O’Leary, 2015, p. 5); from the provision of services by centralized governmental entities to the "hollow state" (Milward \& Provan, 2003; Peters, 1994; Rhodes, 1994) or "third party governance" (Salamon, 2002). Public Administration scholars have conceived of the new governance as the newly emerging paradigm of Public Administration that emphasizes collaboration, networking, and cooperation. As such, the term "governance" becomes "the virtual synonym of public administration" (Frederickson, 2004, p. $5)$.

Researchers have defined the new governance in several ways. Rhodes (1996, p. 652) defines it as "self-organizing, interorganizational networks" that are "alternative to, not a hybrid of, markets and hierarchies." O'Toole (1997a,) defines governance networks in terms of "structures of interdependence involving multiple organizations" (p. 45), emphasizing the salience of networks in public administration, and calling scholars to take these arrangements seriously. Stocker (1998), perceives governance as "the development of governing styles in which boundaries between and within public and private sectors have become blurred" ( $\mathrm{p}$. 117). Viewed this way, governance is broader than government for it transcends the traditional borders of government, thus allowing for public-private collaborative efforts across sectors. As such, the new governance indicates not only a change in the meaning and boundaries of government, but also in the method by which society is governed, whether in terms of policy-making or implementation.

The Resource Dependency theory provides a plausible explanation of the emergence of network arrangements. This theory postulates that individual organizations are not self-sufficient. They do not have the sufficient resources, in terms of human, financial, technological, and information resources, to survive (Pfeffer \& Salanick, 2003). Although public organizations do not die out (Kaufman, 1976), they do need to rely on other organizations for various kind of resources in order to accomplish their goals and to thrive in their environment. This explains why most of public services are no longer exclusively delivered by government organizations but by networks of governmental and nongovernmental actors across sectors that coordinate, collaborate, and allocate resources to address societal problems (Gazley \& Brudney, 2007; Mitchell, 2014). 
In this sense, McGuire (2006) defines collaborative management as "the process of facilitating and operating in multi-organizational arrangements for solving problems that cannot be achieved - or achieved easily - by single organizations" (p. 33 ). Likewise, Keast et al. (2004) conceive of collaborative arrangements as an innovative response to deal with social issues. This paradigm shift also indicates that network arrangements, not government, have come to dominate and control public policy (Peters \& Pierre, 1998). This implies that these nongovernmental or quasi-governmental actors are now equally responsible for policy outcomes (Ansell \& Gash, 2008). This also means that in such arrangements, government is no longer in a position of control and command. Government is, now, one of the actors influencing the course of policymaking and implementation (Peters \& Pierre, 1998; Rhodes, 1996; Salamon, 2002). In these emergent models, all actors are seen as autonomous but dependent on one another to get things done. Thus, in such arrangements, government depends on other actors in the same way that the other actors depend on it (Peters \& Pierre, 1998). Hence, "the command and control of the sovereign, once the hallmark of democratic government," are now replaced by newly emergent models that make "collaboration and negotiation legitimate components of public administrative routine rather than regrettable departure from expected practices" (Salamon, 2002, p. 15).

Other scholars, however, conceive of the collaborative governance as "the new paradigm for governing in democratic systems" (Emerson, Nabatchi, \& Balogh, 2011, p. 3; also see Frederickson, 1991; Jun, 2002; Kettl, 2002; Osborne, 2006), highlighting its contribution to the development of social capital and to the enhancement of citizen participation (Bingham, Nabatchi, \& O'Leary, 2005; Boyte, 2005; Cooper, Bryer, \& Meek, 2006; Hirst, 2000; Kathi \& Cooper, 2005; Nabatchi, 2010; Sørensen, 2002). In this context, Bingham, Nabatchi, and O'Leary (2005) conceive of the citizenry as the other face of the new governance - "the tool makers and tool users" (p. 547) - emphasizing the processes through which they get involved in the work of government.

\section{The Democratic Aspect of the New Governance}

Recently, there has been an increased interest in emphasizing the democratic aspect of the New Governance (Bingham, Nabatchi, \& Balogh, 2005; Cooper, Bryer, \& Meek, 2006; Kathi \& Cooper, 2005; Klijn \& Skelcher, 2007; Nabatchi, 2010; Sørensen, 2002; Sørensen \& Torfing, 2003). Several scholars have acknowledged the fact that the shift from bureaucratic hierarchies to governance networks may challenge the traditional image of liberal democracy, suggesting the reconceptualization and reformulation of the basic concepts of democracy to make them fit the new reality (Boyte, 2005; O’Toole, 1997b; Sørensen, 2002; Sørensen \& Torfing, 2003). This implies reframing the concept of democratic accountability and redefining the concept of democracy.

Reframing Accountability - One of the fundamental concepts that need reconceptualization is democratic accountability. Many PA scholars have acknowledged that the shift from traditional hierarchies to governance networks would challenge governability and raise serious issues about democratic accountability (Acar, Guo, \& Yang, 2006; Agranoff \& McGuire, 2001; Kersbergen \& Waarden, 2004; O’Toole, 1997a, 1997b; Rhodes, 1996, 2000). 
Rhodes (1996, 2000) argues that because governance networks are self-organizing, autonomous, not accountable to the state, resist steering and central guidance, there is a fear that these network arrangements deviate from the public interest, and end up by pursuing their own interests instead. Thus, hollowing out the state presents a real challenge to the traditional concept of accountability (Peters \& Pierre, 1998; Rhodes, 1996, 2000).

Unlike traditional public administration and NPM in which accountability is the strongest point of the model, accountability in the new governance model remains the weakest link. In governance network settings, accountability is diffused unlike accountability in both traditional public administration and NPM which is well defined. In traditional hierarchies, accountability is determined in terms of hierarchical control and external oversight, whereas under NPM, accountability is defined in terms of accountability for results that can be measured against targets' attainment and consumer choice.

Public Administration (PA) scholars have agreed that different forms of accountability are needed in governance network settings that may serve functions beyond hierarchical control and external oversight. Accountability in governance networks has more to do with identifying the different expectations of network actors, aligning goals, adjusting strategies, assessing implementation, communicating performance, and facilitating learning (Acar, Guo, \& Yang, 2008; Bardach \& Lesser, 1996; Roberts, 2002).

Redefining Democracy - The shift from government to governance also indicates "a shift in the meaning of democracy from election to democratic society" (Boyte, 2005, p. 518). This shift, Boyte (2005) and Thomas (2013) argue, represents a move from perceiving citizens as voters, consumers, or volunteers to seeing them as participators in the problem solving process and co-creators of public goods. In this sense, the concept of "deliberative democracy" with its emphasis on "government by information exchange and consent" (Hirst, 2000, p. 27) has been proposed as a solution to the problem of accountability (Kersbergen \& Waarden, 2004; Sørensen, 2002; Sørensen \& Torfing, 2003). Scholars have contended that deliberative democracy provides citizens and stakeholders with the opportunity to voice their needs and concerns, and allows for the development of more responsive, citizen-centered collaborative management systems, partnerships, and strategies (Cooper, Bryer, \& Meek, 2006; Emerson, Nabatchi, \& Balogh, 2011; Kathi \& Cooper, 2005; Nabatchi, 2010).

These collaborative interactive processes have the potential to promote transparency, accountability and, hence, legitimacy (Emerson, Nabatchi, \& Balogh, 2011); to build trust and create mutual understanding (McGuire, Agranoff, \& Silvia, 2010, p. 20); to enhance citizen engagement and public dialogue and to, ultimately, generate more informed and democratic decisions (Bingham, Nabatchi, \& O’Leary, 2005).

In an attempt to reframe the meaning of democracy in our contemporary society, O'Toole (1997b, p. 448) identifies a framework of three fundamental democratic values that need to be pursued: 1) responsibility for effecting the public interest; 2) responsiveness to public preferences; and 3) political deliberation, civility, and trust. In the next section, we discuss how the information society would help in promoting these democratic ideals. 


\section{The Role of the Information Society in Promoting a More Democratic Governance}

Change is accelerating in our times. It invades our life, transforms our institutions, and shifts our ways of interaction and communication. Perhaps, the most remarkable change that societies around the globe have been witnessing in the past few decades is the advent and the widespread use of ICTs. This technological revolution - or what Floridi (2014) calls the "Fourth Revolution" - has ushered an unparalleled era in history - an era of boundless change, mobility, and possibilities for both individuals and organizations.

The use of ICTs has dramatically changed the way by which government - and its collaborative partners - work, and presented both opportunities and ethical challenges to the new governance. This section discusses how the "information society," and the "infosphere" governing it, contributes to the process of reframing and redefining democracy, and the ethical challenges that come along with it. By the infosphere, we mean the ecological domain of the information society that is provided by the use of ICTs - a parallel digital world where boundaries are dissolved, "where information functions as a type of substance that animates orders and delimits human activity as both a field of possibility and constraint" (Mukherjee, 2013, p. 4).

In this essay we argue that not only has the use of ICTs enabled various modes of communications within governance network and allowed the easy exchange of information between network actors and stakeholders (Agranoff, 2006), but it also plays an important role in generating a more democratic governance by increasing transparency, building trust relationship, and promoting deliberative civic discourse.

\section{Increasing Transparency and Accountability}

Transparency is an apriori condition for democratic accountability, and a critical component for the efficiency and well-functioning of governance networks. Transparency has been viewed as a tool to enhance accountability, to curb corruption, and to improve network performance. The use of ICTs has facilitated the ability of governance networks to provide and share information about their performance digitally. Through the use of ICTs, governance networks can increase their visibility by publically disclosing their goals, projects, and activities, whether via websites, annual reports, brochures, or other forms of online public disclosures.

Improving information sharing through ICTs is critical to improve the quality of policy decisions and public service delivery. In this sense, transparency of information improves network performance; increases networks' responsiveness to public preferences; enhances their capacity to meet citizens' needs; and builds trust between network actors, as well as between networks and the citizenry. Putnam (2000) observes that citizen satisfaction with government performance is the outcome of both citizen expectations and perception of government performance. In short, transparency and information sharing help governance networks achieve their objectives and be held responsible for their results, thus mitigating the public distrust in government and its collaborators. 


\section{Building Trust Relationships}

Many scholars have maintained that trust may play a critical role in network arrangements (Ansell \& Gash, 2008; Klijn, Edelenbos, \& Steijin, 2010; Klijn \& Koppenjan, 2012), highlighting the role of network managers in building trust within and outside networks - that is, among network actors and between networks and the citizenry. As such, trust in governance networks is a two-way process. The first can be achieved through alignment of goals and strategies, the second through citizen participation and engagement. Both ways can be facilitated through the proper use of ICTs.

Trust within networks improves network performance; reduces strategic uncertainty and complexity; enhances information sharing; fosters a learning culture; improves decision-making processes and the quality of decisions; and helps in developing innovative solutions to societal problems. Trust outside networks can be achieved through transparency, information sharing, and by providing formal ways for citizens to channel their grievances and concerns and to seek correction of mistakes. Trust outside networks improves participation; helps building social capital; and improves the quality and legitimacy of policy decisions as well as service delivery.

\section{Promoting Deliberative Civic Discourse}

The future of democratic governance depends a great deal on an educated and well-engaged citizenry and on the ability of government, and its collaborators, to make better choices and well-informed decisions. This can only be achieved by bringing government closer to the public and by increasing participation (Garrett, 2006). Through the use of ICTs, the information society provides the opportunity for citizens to get engaged in deliberative civic discourse which is essentially important for developing public support for both policy decisions and implementation (O'Toole, 1997b). The information society makes this possible through the creation of a new public sphere and virtual communities (Losifidis, 2011).

Public spheres are cultural arenas whereby people come together to articulate their views and voice their concerns in order to influence policies. Habermas (1996), contends that "between the state and society lies the public sphere, a network for communicating information and points of views" (p. 360). The "traditional Habermasian concept of the national public sphere created by the mass media of newspapers and television is said to have transformed to a multi-layered sphere of online and social networks which are increasingly important in engaging and mobilizing citizenship and in shaping the discourse within which rational discussion takes place" (Losifidis, 2011, p. 619). Thus, the information society has allowed the formation of virtual public spheres and communities that connect people anywhere on any issue of their concern. These vibrant, virtual networks are capable of generating social capital, which constitutes the cornerstone in building trust relationship and in making democracy work (Putnam, 1993).

Engaging the citizenry in democratic practices brings new insights into the policy processes that would feed and inform decisions about the public needs and preferences. This would help engender "both a democratic ethos and consensual decision-making outcomes" (Klijn \& 
Sklecher, 2007, p. 9); improve the quality of delivered services and the legitimacy of decisions; and attenuate mistrust in government.

This leads us to conclude that the proper use of ICTs will be central to the new models of democracy. By promoting transparency, trust, and deliberative civic discourse, the information society provides the tools and the mechanisms for more democratic governance.

\section{The Dark side of Transparency}

However, the infosphere has made transparency - the cherished ethical value by both NPM and the new governance - both an opportunity and a constraint. Open record laws have made government information - including people's private and sensitive information such as medical records and social security numbers - accessible to the public. These laws often conflict with confidentiality and privacy protection laws. Taken into consideration cyber-crimes and attacks, transparency may result in unintended consequences for both network actors and the public in general.

The recent cyber-attacks have recently shown that enormous cloud servers, in which data from various communication activities (phone calls, emails, text messages, social media activities, etc.) of millions of individuals around the globe are collected and stored, can be breached. Thus, "data are leaky, and they escape in unexpected ways be it through errors, hacks, or whistleblowing" (Boyd \& Crawford 2012, p. 1666).

The challenge to governance networks is to enhance transparency without violating privacy, and to provide legal protections to assure fair treatment for both network actors and the public. After all, information resources are an important asset of any organization, whether public or private. Any misuse or abuse of information may generate undesirable consequences. As such, information integrity is critical to the well-being and well-functioning of governance networks. Inaccurate or incomplete information may result in misguided or ill-advised decisions that could have, otherwise, been avoided (Posthumus \& Von Solms, 2004).

\section{Guidelines for Managers in Governance Networks}

PA scholars have acknowledged the importance of the role of public and private mangers in managing networks (Agranoff \& McGuire, 2001; McGuire, Agranoff, \& Silvia, 2010; Milward \& Provan, 2003; O'Toole, 1997a). This role goes beyond the role of public mangers in traditional bureaucracies. Managers of governance networks are expected to negotiate; to align goals; to integrate strategies; to build trust; to promote collaboration; to provide incentives for joint efforts; and to nurture ethical organizational cultures.

To ensure the well-functioning of governance networks, network managers should pay due attention to the relationship between networks and the citizenry. Improving citizen participation requires taking information integrity and security seriously. In this sense, information security should be a priority and a responsibility of governance networks. As such, information security should not be viewed as a purely "technical concern" but as a "strategic concern" (Posthumus \& Floridi, 2004, p. 638). This requires that all collaborative 
stakeholders, including citizens, understand the importance of information security and all sorts of risks that affect it.

In the same vein, overcoming the ethical challenges that come along with the use of ICTs entails that governance networks conform to the ethics of the infosphere - the ecological ethics that governs the use, access, and dissemination of information in the information society (Floridi, 2014; Ramadhan, Sensuse, \& Arymurthy, 2011). This can be achieved by developing a well-articulated and detailed ethical statement for the proper use of ICTs either by network actors or by the public; by embedding protection mechanisms for the use, access, and dissemination of information; by raising awareness about the ethical dimension of the use of ICTs among network actors and stakeholders; and by taking preventive measures as determined by laws against any misuse or abuse of information. In short, addressing the ethical dimension of the use of ICTs requires joint efforts not only of network actors and service providers but also of regulatory bodies and individual users. Ensuring information security is fundamental to enhance trust and to improve the quality of decisions.

Improving the outcomes of citizen participation through the use of ICTs also requires that government takes serious actions to reduce digital inequalities (Halford \& Savage, 2010; Robinson et al., 2015) or the digital divide between the haves and the have nots. This can be achieved by developing communication platforms that can be accessed by everyone, so that every citizen will have the opportunity to enhance his life choices by participating in the decision process.

In short, the proper use of ICTs will help governance networks in promoting transparency while protecting privacy; fostering trust within and outside networks; nurturing ethical environment whereby achieving the public good is the higher ideal and the ultimate objective of all actors in the network structure; and promoting more democratic settings through citizen participation - these settings will promote better informed citizenry, enhanced accountability, equity, and responsiveness to public preferences.

Based on the argument made in this paper, we offer a set of propositions and a framework to be empirically assessed by future research.

Proposition 1 - Increased citizen participation through ICTs will improve the quality of network decision in policy networks.

Proposition 2 - Increased citizen participation through ICTs will improve the quality of delivered services. This will result in increased citizen satisfaction with government performance.

Proposition 3 - Citizen participation through ICTs will enhance the formation of social capital which, in turn, will improve the legitimacy of policy decisions and implementation as well as enhance democratic accountability.

Proposition 4 - Information sharing among network actors through ICTs will increase trust within networks which, in turn, will improve network performance.

Proposition 5 - Transparency of network decisions and activities will reduce citizen distrust 
in government performance.

Proposition 6 - Improving information security will enhance citizen participation. This, in turn, will provide more inputs, resulting in more informed decisions.

Proposition 7 - Improving information security will improve information sharing within networks, and, eventually, generate better decisions and, hence, better network performance.

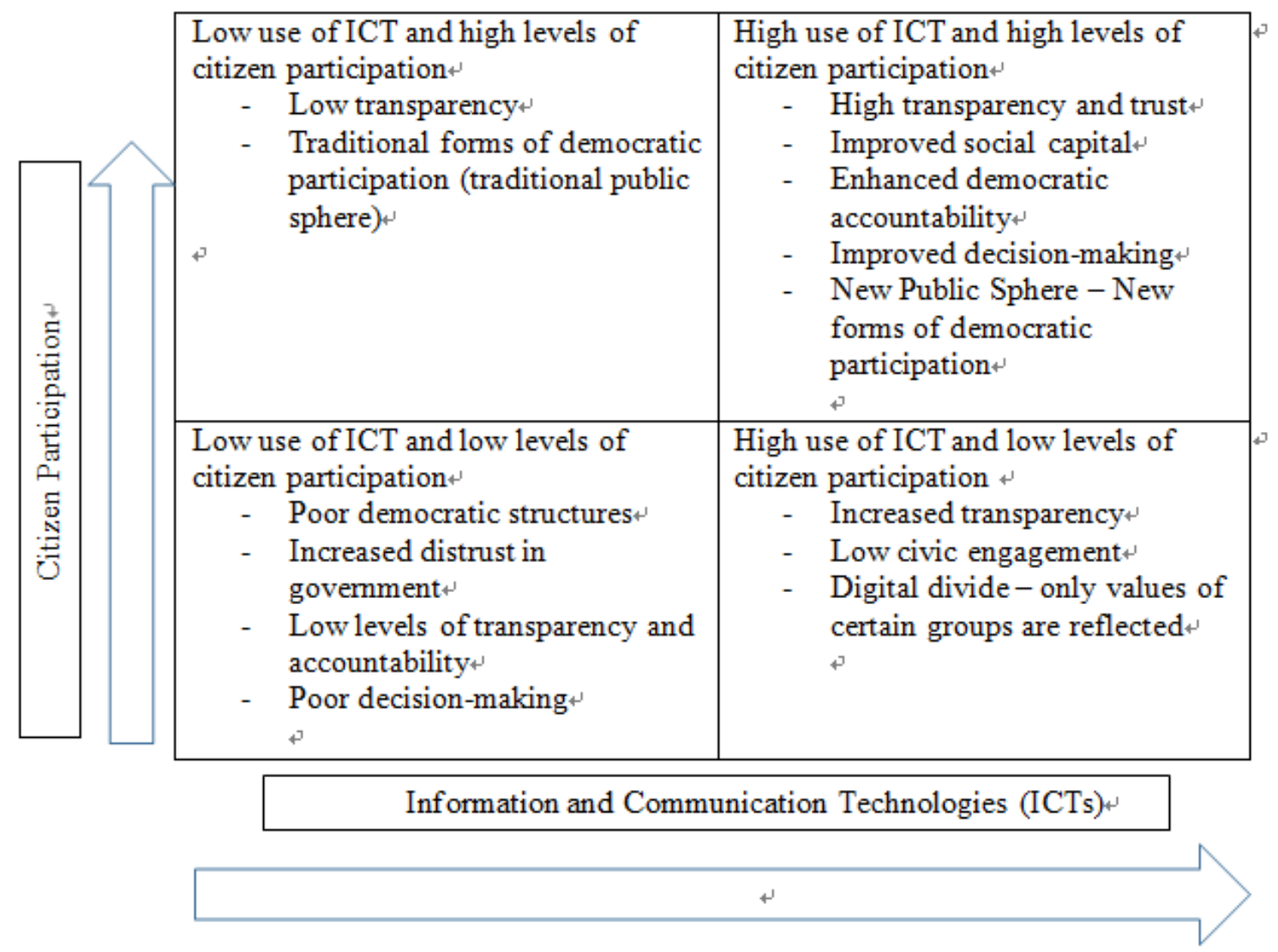

Figure 1. Citizen Participation and use of Information and Communication Technologies (ICTs) by Government

\section{Conclusion}

Writing more than 60 years ago, Dwight Waldo wrote that "democracy is very much more than the political context in which public administration is carried out" (Cited in O'Toole, 1997b, p. 443). This paper argues that the new governance does not constitute a departure from the democratic ethos that traditional Public Administration sought to cherish, but a reassertion of this ethos in a way that speaks to the new reality of our time. The argument that we sought to develop in this paper is that the information society holds the promise to promote a better governance that is more compatible with the democratic ideals of our society. The extension of the cyber-sphere to citizens and citizen discourse is not merely a function of the technological advances. Citizen engagement via discourse is a precursor to the introduction of ICTs for improving participation in the public sphere (Dahlberg, 2001). As such, enhancing citizen participation through the use of ICTs will not only add to the quality 
of the services they receive, but will also make democracy work more properly in our vexing times. In this sense, ICTs can be viewed as a tool for democracy. However, like any tool, if it is not properly used, it would generate undesirable consequences.

In the age of drones, cyber surveillance (West and Bowman 2016), and ICTs more attention should be paid to the ethical prospects and problems that may arise from the use of these technologies in order to get the best out of them. Therefore, in order to promote citizen participation through the use of ICTs, government is called upon not only to provide the necessary infrastructure and the easy and inexpensive access to these technologies, but also to invest in the integrity and security of shared data thus, ultimately, providing a safe zone for grassroots participation.

\section{References}

Acar, M., Guo, C., \& Yang, K. (2008). Accountability when hierarchical authority is absent: Views from public-private partnership practitioners. The American Review of Public Administration, 38(1), 3-23. https://doi.org/10.1177/0275074007299481

Agranoff, R. (2006). Inside collaborative networks: Ten lessons for public managers. Public Administration Review, 66(s1), 56-65. https://doi.org/10.1111/j.1540-6210.2006.00666.x

Agranoff, R., \& McGuire, M. (2001). Big questions in public network management research. Journal of Public Administration Research and Theory, 11(3), 295-326. https://doi.org/10.1093/oxfordjournals.jpart.a003504

Ansell, C., \& Gash, A. (2008). Collaborative governance in theory and practice. Journal of Public Administration Research and Theory, 18(4), 543-571. https://doi.org/10.1093/jopart/mum032

Bardach, E., \& Lesser, C. (1996). Accountability in human services collaboratives-for what? and to whom?. Journal of Public Administration Research and Theory, 6(2), 197-224. https://doi.org/10.1093/oxfordjournals.jpart.a024307

Bennis, W. G. (1966). Changing organizations. The Journal of Applied Behavioral Science, 2(3), 247-263. https://doi.org/10.1177/002188636600200301

Bingham, L. B., Nabatchi, T., \& O'Leary, R. (2005). The new governance: Practices and processes for stakeholder and citizen participation in the work of government. Public Administration Review, 65(5), 547-558. https://doi.org/10.1111/j.1540-6210.2005.00482.x

Boyd, D., \& Crawford, K. (2012). Critical questions for big data: Provocations for a cultural, technological, and scholarly phenomenon. Information, communication \& society, 15(5), 662-679. https://doi.org/10.1080/1369118X.2012.678878

Boyte, H. C. (2005). Reframing democracy: Governance, civic agency, and politics. Public Administration Review, 65(5), 536-546. https://doi.org/10.1111/j.1540-6210.2005.00481.x

Cooper, T. L., Bryer, T. A., \& Meek, J. W. (2006). Citizen - centered collaborative public management. Public Administration Review, 66(s1), 76-88. 
https://doi.org/10.1111/j.1540-6210.2006.00668.x

Dahlberg, L. (2001). The Internet and democratic discourse: Exploring the prospects of online deliberative forums extending the public sphere. Information, Communication \& Society, 4(4), 615-633. https://doi.org/10.1080/13691180110097030

Emerson, K., Nabatchi, T., \& Balogh, S. (2012). An integrative framework for collaborative governance. Journal of Public Administration Research and Theory, 22(1), 1-29. https://doi.org/10.1093/jopart/mur011

Floridi, L. (2014). The fourth revolution: How the infosphere is reshaping human reality. OUP Oxford.

Frederickson, H. G. (1991). Toward a theory of the public for public administration. Administration \& Society, 22(4), 395-417. https://doi.org/10.1177/009539979102200401

Frederickson, H. G. (2004). Whatever Happened to Public Administration? Governance, Governance, Everywhere. Queens University Institute of Governance. Public Policy and Social Research Working Paper.

Garrett, R. (2006). Protest in an information society: A review of literature on social movements and new ICTs. Information, Communication \& Society, 9(02), 202-224. https://doi.org/10.1080/13691180600630773

Gazley, B., \& Brudney, J. L. (2007). The purpose (and perils) of government-nonprofit partnership. Nonprofit and Voluntary Sector Quarterly, 36(3), 389-415. https://doi.org/10.1177/0899764006295997

Habermas, J. (1996). Between facts and norms: Contributions to a discourse theory of law and democracy. Cambridge, MA: MIT Press

Halford, S., \& Savage, M. (2010). Reconceptualizing digital social inequality. Information, Communication \& Society, 13(7), 937-955. https://doi.org/10.1080/1369118X.2010.499956

Hirst, P. (2000). Democracy and Governance in Debating Governance: Authority, Steering and Democracy, edited by Jon Pierre, 13-35.

Jun, J. S. (2002). Rethinking administrative theory: The challenge of the new century. Westport, CT: Greenwood Publishing Group.

Kathi, P. C., \& Cooper, T. L. (2005). Democratizing the administrative state: Connecting neighborhood councils and city agencies. Public Administration Review, 65(5), 559-567. https://doi.org/10.1111/j.1540-6210.2005.00483.x

Katz, D., \& Kahn, R. L. (1978). The social psychology of organizations (Vol. 2). New York: Wiley.

Kaufman, H. (1976). Are government organizations immortal?. Washington, D.C.: The Brookings Institute.

Keast, R., Mandell, M. P., Brown, K., \& Woolcock, G. (2004). Network structures: Working 
differently and changing expectations. Public Administration Review, 64(3), 363-371. https://doi.org/10.1111/j.1540-6210.2004.00380.x

Kersbergen, K. V., \& Waarden, F. V. (2004). 'Governance' as a bridge between disciplines: Cross - disciplinary inspiration regarding shifts in governance and problems of governability, accountability and legitimacy. European Journal of Political Research, 43(2), 143-171. https://doi.org/10.1111/j.1475-6765.2004.00149.x

Kettl, D. (2002). The transformation of Governance: Public Administration for Twenty-first Century America. Baltimore, MD: Johns Hopkins University Press.

Kettle, D. (1993). Sharing power: Public governance and private markets. Washington, DC: Brookings Institute.

Klijn, E. H., \& Koppenjan, J. (2012). Governance network theory: Past, present and future. Policy \& Politics, 40(4), 587-606. https://doi.org/10.1332/030557312X655431

Klijn, E. H., \& Skelcher, C. (2007). Democracy and governance networks: Compatible or not?. Public Administration, $\quad$ 85(3), 587-608. https://doi.org/10.1111/j.1467-9299.2007.00662.x

Klijn, E. H., Edelenbos, J., \& Steijn, B. (2010). Trust in governance networks: Its impacts on outcomes. Administration \& Society, 42(2), 193-221. https://doi.org/10.1177/0095399710362716

Losifidis, P. (2011). The public sphere, social networks and public service media. Information, Communication \& Society, 14(5), 619-637. https://doi.org/10.1080/1369118X.2010.514356

McGuire, M. (2006). Collaborative public management: Assessing what we know and how we know it. Public Administration Review, 66(s1), 33-43. https://doi.org/10.1111/j.1540-6210.2006.00664.x

McGuire, M., Agranoff, R., \& Silvia, C. (2010). Collaborative public administration. The Foundations of Public Administration Series, 61(6), 671-681.

Milward, H. B., \& Provan, K. (2003). Managing the hollow state Collaboration and contracting. Public Management Review, 18 5(1), https://doi.org/10.1080/1461667022000028834

Mitchell, G. E. (2014). Collaborative propensities among transnational NGOs registered in the United States. The American Review of Public Administration, 44(5), 575-599. https://doi.org/10.1177/0275074012474337

Mukherjee, R. (2013). Ethical and Societal challenges of the Information Society. Background Report Prepared for the WSIS. UNESCO.

Nabatchi, T. (2010). Addressing the citizenship and democratic deficits: The potential of deliberative democracy for public administration. The American Review of Public Administration, 40(4), 376-399. https://doi.org/10.1177/0275074009356467 
O'Leary, R., Gerard, C., \& Bingham, L. B. (2006). Introduction to the symposium on collaborative public management. Public Administration Review, 66(s1), 6-9. https://doi.org/10.1111/j.1540-6210.2006.00661.x

O'Leary, R. (2015). From silos to Networks. In Public Administration Evolving: From Foundations to the Future (85-100). American Society for Public Administration. New York: Routledge.

Osborne, S. (2006). The New Public Governance? Public Management Review, 8(3), 377-387. https://doi.org/10.1080/14719030600853022

O'Toole, L. J. (1997). The implications for democracy in a networked bureaucratic world. Journal of Public Administration Research and Theory, 7(3), 443-459. https://doi.org/10.1093/oxfordjournals.jpart.a024358

O'Toole, L. J. (1997). Treating networks seriously: Practical and research-based agendas in public administration. Public Administration Review, 57(1), 45-52. https://doi.org/10.2307/976691

Peters, B. G. (1994). Managing the hollow state. International Journal of Public Administration, 17(3-4), 739-756. https://doi.org/10.1080/01900699408524915

Peters, B. G., \& Pierre, J. (1998). Governance without government? Rethinking public administration. Journal of Public Administration Research and Theory, 8(2), 223-243. https://doi.org/10.1093/oxfordjournals.jpart.a024379

Pfeffer, J., \& Salancik, G. R. (2003). The external control of organizations: A resource dependence perspective. Redwood, CA: Stanford University Press.

Posthumus, S., \& Von Solms, R. (2004). A framework for the governance of information security. Computers \& Security, 23(8), 638-646. https://doi.org/10.1016/j.cose.2004.10.006

Putnam, R. D. (1993). Making Democracy Work: Civic Traditions in Modern Italy. Princeton, NJ: Princeton University Press.

Putnam, R. D. (2000). Bowling Alone: America's Declining Social Capital. In Culture and Politics, pp. 223-234. London, UK: Palgrave Macmillan.

Ramadhan, A., Sensuse, D. I., \& Arymurthy, A. M. (2011). E-government ethics: A synergy of computer ethics, information ethics, and cyber ethics. e-Government, 2(8). https://doi.org/10.14569/IJACSA.2011.020816

Rhodes, R. A. (1994). The hollowing out of the state: The changing nature of the public service in Britain. The Political Quarterly, 65(2), 138-151. https://doi.org/10.1111/j.1467-923X.1994.tb00441.x

Rhodes, R. A. (1997). Understanding governance: Policy networks, governance, reflexivity and accountability. UK: Open University Press.

Rhodes, R. A. (2000). Governance and public administration. In Debating Governance: 
Authority, Steering and Democracy (pp. 54-90). Oxford: Oxford University Press.

Rhodes, R. A. W. (1996). The new governance: Governing without government. Political Studies, 44(4), 652-667. https://doi.org/10.1111/j.1467-9248.1996.tb01747.x

Robert, A., \& Michael, M. (2003). Collaborative public management: New strategies for local governments. Washington, DC: Georgetown University Press.

Roberts, N. C. (2002). Keeping public officials accountable through dialogue: Resolving the accountability paradox. Public Administration Review, 62(6), 658-669. https://doi.org/10.1111/1540-6210.00248

Robinson, L., Cotten, S. R., Ono, H., Quan, H. A., Mesch, G., Chen, W., ... \& Stern, M. J. (2015). Digital inequalities and why they matter. Information, Communication \& Society, 18(5), 569-582. https://doi.org/10.1080/1369118X.2015.1012532

Salamon, L. M. (2002). The Tools of Government: A Guide to the New Governance. UK: Oxford University Press.

Sørensen, E. (2002). Democratic theory and network governance. Administrative Theory \& Praxis, 24(4), 693-720.

Sørensen, E., \& Torfing, J. (2003). Network politics, political capital, and democracy. International Journal of Public Administration, 26(6), 609-634. https://doi.org/10.1081/PAD-120019238

Stoker, G. (1998). Governance as theory: five propositions. International Social Science Journal, 50(155), 17-28. https://doi.org/10.1111/1468-2451.00106

Thomas, J. C. (2013). Citizen, customer, partner. Rethinking the place of the public in public Management, Public Administration Review, 73(6), 786-796. https://doi.org/10.1111/puar.12109

West, J. P., \& Bowman, J. S. (2016). The Domestic Use of Drones: An Ethical Analysis of Surveillance Issues. Public Administration Review, 76(4), 649-655. https://doi.org/10.1111/puar.12506

\section{Copyright Disclaimer}

Copyright for this article is retained by the author(s), with first publication rights granted to the journal.

This is an open-access article distributed under the terms and conditions of the Creative Commons Attribution license (http://creativecommons.org/licenses/by/4.0/). 